\title{
Geographical Distribution of Vegetation in Yorkshire
}

\section{Author(s): William G. Smith}

Source: The Geographical Journal, Vol. 21, No. 4 (Apr., 1903), pp. 375-401

Published by: geographicalj

Stable URL: http://www.jstor.org/stable/1775680

Accessed: 27-06-2016 06:23 UTC

\section{Your use of the JSTOR archive indicates your acceptance of the Terms \& Conditions of Use, available at}

http://about.jstor.org/terms

JSTOR is a not-for-profit service that helps scholars, researchers, and students discover, use, and build upon a wide range of content in a trusted digital archive. We use information technology and tools to increase productivity and facilitate new forms of scholarship. For more information about JSTOR, please contact support@jstor.org.

The Royal Geographical Society (with the Institute of British Geographers), Wiley are collaborating with JSTOR to digitize, preserve and extend access to The Geographical Journal 
Persia, and into north-eastern India, has witnessed the rise and decay of many an empire, the grandeur of which has been due to the little threads of water which have trickled over its lands guided by the hands of the husbandman. The human race appears to seek such arid districts by preference, and this has been so from the earliest times, as is attested by the ruined cities of Central Asia. The Peruvian neglected the fertile lands of the Amazon valley slope for the arid lofty plateaux of the Andes. Similarly, the Mexicans shunned the tropical districts for the dry tablelands, which, by irrigation, they made the basis of a state which reached the highest status of barbarism found in any country of the New World by the Spanish conquerors. To-day the United States has adopted a plan for irrigating its arid lands on a vast scale, and is applying a fund of sereral millions of dollars yearly to the work with immense beneficial results. In California, from 10 to 20 acres of irrigated land are now considered as the equivalent of 160 not thus treated.

Would it not be wise to give the native population of East Africa a few objectlessons in irrigation? Perhaps the judicious application of $£ 100,000$ would do this with great resultant benefit to the railway and to all concerned. I think it only remains for me to thank Mr. Buckley for his extremely interesting paper, knowing that in doing so I only express your wishes.

\section{GEOGRAPHICAL DISTRIBUTION OF VEGETATION IN YORKSHIRE.}

By Dr. WILLIAM G. SMITH, Yorkshire College, Leeds, and C. E. MOSS, B.Sc.

\section{INTRODUCTION.}

THe two maps * and accompanying text, here submitted, are the results of a survey of the vegetation in the West Riding of Yorkshire, conducted on principles which have not previously been employed in England. The work was begun in 1898, in order to test in Yorkshire the method of botanical survey which the late Robert Smith was at that time developing in Scotland. On the completion in 1900 of the first maps of the Scottish Botanical Survey-Edinburgh and North Perthshire (1900) $\dot{T}$-it became evident that the method gave good results; and the survey of the West Riding was then systematically undertaken as opportunity offered. The first results of the experiment, maps covering over 1700 square miles and a summary of observations, are now submitted. It is considered most convenient to publish these in two parts, the first including the south-western district of the West Riding, the second including the north-east part of the Riding. In the first part Mr. Moss's work is incorporated, Mr. Rankin's in the

* The second paper and map will probably be published in June.

+ 'The numbers in brackets after an author's name indicate the year in which a book or paper was published. The titles of the works referred to will be found in the List of References at the end of this paper. The authors' names are arranged alphabetically, and the papers of each author in chronological order, with the year-number in brackets. In the case of a periodical, the number in brackets is the year of publication of the paper referred to. 
second part, although their observations have by no means been strictly confined to these areas. The survey has been carried beyond the limits of the present maps, and practically all the West Riding, with parts of the North Riding, are completed. It is, however, advisable to keep the maps uniform in size, and to issue them as a series, so that the work done beyond the present limits will appear later.

The principles of the method have already been explained elsewhere, but a brief summary will probably be useful. The vegetation of any area may be considered from two aspects, distinct yet closely related. One may set out to find an answer to the question, "What species occur here?" or to solve "How are the species arranged with regard to one another, and with regard to soil and climate?" The result in the former case would be a flora; in the latter it would be a connected account of the vegetation. The floristic method has as its first object the recording of all the species found in an area; these, arranged under genera and natural orders, with notes on habitat and frequency or rarity, would constitute the flora of the district. The present and past distribution of the species or genera over the Earth, and the history and migration of the race, are wider questions of floristic interest. The botanical characters of most importance here are those of the race, especially the floral organs. The production of floristic maps in Britain was begun by H. C. Watson (1843); these showed the areas of distribution of species or genera.

The study of vegetation, on the other hand, recognizes that there is a close connection between the plants of a country or other area, and the prevailing conditions of soil and climate. Thus the vegetation of a dry district is distinct from that of a rainy one; or, in a narrower sense, the vegetation of an upland pasture is different from that of a lowland marsh. In the floristic sense, the plants growing together under uniform conditions of soil and climate may have no kinship; yet the fact that they grow together indicates an ocological relationship. From this aspect, " the essential characters of the species are those indicating adaptation to the environment, and are to be found mainly in the vegetative organs" (Smith, R., 1899). After some experience in examining vegetation, the recognition of biological communities or societies is acquired. However large or small the number of species included in such a plant-society may be, it is possible to arrange them under three subdivisions. (1) Dominant social forms: one or more species, whose presence is in the first place determined by conditions of climate, soil, and environment suited to their requirements; while their dominance is the result of gregarious or social habit. Thus heather and grasses are dominant social forms, while trees, also social, obtain an additional advantage from size and age. (2) Secondary or subordinate social forms struggling for dominance. (3) Dependent species 
protected by the dominant forms, or living in the humus beneath them. The scope of such a plant-society may be wide or narrow, according to the selection of dominant forms. For example, heather, grasses, oak, and pine are four dominant social forms characteristic of groups which are wide and inclusive. These may be designated types of vegetation. Within a heather moor smaller communities exist where Calluna, Erica Tetralix, or Juncus are characteristic of more or less limited spheres dependent upon local conditions of soil and water-supply. These are narrower in their scope, and may be called plant-associations. In describing any region the selection of associations or types depends largely on how detailed a survey is attempted.

The plan followed in the present survey is largely founded on the work of Prof. Flahault, of Montpellier, who is carrying out a survey of the vegetation of France based on the distribution of certain trees (1897). A number of trees are social, and tend to form forests where one or two species prevail and more or less completely exclude all others. From a geographical point of view, forests of a particular tree indicate certain climatic and soil conditions ; from a botanical point of view, the presence of particular associations of subordinate species; and from an economic point of view, regions suitably situated for the growth of certain cultivated species and for certain industries. The botanical survey of Scotland was a direct outcome of Flahault's work; for R. Smith, while a student at Montpellier, accompanied him on excursions. Flahault's method of representing the vegetation by recording the distribution of selected forest trees on a map was at first proposed in Scotland; but $R$. Smith decided that this would give an inadequate, if not erroneous, impression of the plant-covering of the country. The almost total absence of primitive forest in Britain and the great proportion of cultivated land have so changed the original and natural vegetation of the country, that a map according to Flahault must be to a'great extent hypothetical. R. Smith then decided that a statistical map of the vegetation was first necessary as a basis in preparing either forest maps or maps showing the plant associations. A scheme of types of vegetation was drawn up; and the results already published (1900), as well as unpublished, show that the method will do much to assist towards a clearer conception of the vegetation of Britain. The same principles have been applied in Yorkshire.

Detailed maps of vegetation representing natural subdivisions of North America are constructed by the staff of the U.S.A. Department of Agriculture (1898). In the series of monographs edited by Engler and Drude (1897), vegetation maps are also issued, but the scale used is much smaller than in our case. Maps of isolated forest areas, with the dominant trees indicated by colouring, have also been prepared for many parts of France, Germany, and Russia, but none of them attempt a continuous area. 
The general programme of a vegetation survey was discussed by R. Smith (1900). The chief points to be considered may be summarized as follows :-

(a) The chief zones or regions, characterized by definite plant associations, into which the district may be most conveniently divided.

(b) The particular conditions of soil and atmosphere which distinguish each zone or region.

(c) The adaptations of the plant-species to their environment.

(d) The relations existing between the species-that is, which species are dominant, which subdominant, and which dependent upon the dominant species for shelter or for food.

(e) The influence of animals and of man upon the associations.

( $f$ ) The general conditions of climate and of vegetation in the district compared with those in other districts.

The method of survey is to traverse the selected area till its prominent associations are recognized. The extent of country observed in a single excursion is variable, and depends on whether the vegetation is uniform and easily accessible, or the contrary. It may be necessary to traverse a difficult area at distances of a few hundred yards; but the routes may be farther apart where the vegetation seen from a distance is found to be uniform. Opportunities of checking previous observations occur when a place already visited is seen from another vantage, or when two routes cross, as they frequently do. In preparing the maps, the limits of prominent associations are ascertained and recorded on the field-map on the spot. The maps used for outdoor work are generally the " 1 -inch" sheets of the Ordnance Survey, although in some cases the "6-inch-to-mile" sheets are preferable. The published maps are on the scale of 1 -inch to 2 miles; a convenient size for publication with a small number of types of vegetation. The number of types on the published maps does not, however, represent all those recognized in field-work, but they are taken as sufficient to effect a primary analysis of the vegetation. A less apparent but more important work is to collect information regarding associations. When an association is recognized, the plants found there are recorded in a field notebook, with the order of their occurrence as dominant, secondary, or dependent species, also their state of flowering. Other observations are made regarding subjacent rocks or deposits, conditions of drainage, altitude, exposure, and environment generally. The records thus obtained are important not only as information about the vegetation and its local conditions, but also as standards for comparison. One type of vegetation has to be compared with another quite distinct in character; or it frequently happens that an association as developed in one place has to be compared with another somewhat similar, but in a different locality. It is only by careful notes that one overcomes the difficulty of carrying on the survey during a series of 
excursions extending through two or three years. The field-notes are also invaluable when one observer wishes to compare results with another.

The maps are prepared entirely from our own observations; but in the preparation of the paper the existing literature on the vegetation of the West Riding has not been ignored. The 'Flora of West Yorkshire' (F. A. Lees, 1888) and 'North Yorkshire' (J. G. Baker, 1885) are indispensable in considering the plant geography of the county. In both these works, Thurmann's (1849) attempt to classify vegetation according to the mechanical constitution of the underlying rock has been adapted to Yorkshire; and lists of characteristic species given. 'West Yorkshire' (Davis and Lees, 1880) has also been referred to, especially for the lists of plants of definite localities, which have been useful guides, although not arranged according to the principles followed in this survey. In matters relating to the geology of the area we are indebted to Mr. P. F. Kendall, of Yorkshire College, in a degree which is beyond formal acknowledgment. The introduction to Mr. Crump's 'Flora of Halifax' (1901) has proved of great service, because it follows the lines of our work. Other sources of information are Mr. Rothery's 'Flora of Skipton,' and the publications of the Yorkshire Naturalists' Union. We have also to acknowledge assistance from Mr. T. W. Woodhead, of Huddersfield, on the flora of that area; Mr. R. C. Gaut for assistance in the survey of parts, and for lists; and many others who have taken the trouble to ascertain details necessary to the survey. We have specially to acknowledge our great indebtedness to Mr. J. G. Bartholomew, not only for the reproduction of the maps, but for much assistance in other ways.

\section{PART I.: LEEDS AND HALIFAX DISTRICT.*}

If the area represented in the present map be traversed from east to west on one of the railroads, the impression is first received of a thickly populated manufacturing area, with numerous collieries. In the western half, towns are less numerous; and valleys with grassy slopes, dotted with villages and homesteads, are presented. The woods are limited to the stream-sides, while moorland edges form a fringe along the skyline. With the aid of a good map, such as those of the Ordnance Survey or Messrs. Bartholomew's latest maps of the county, the towns seen in their true proportions are found to occupy less of the area than the earlier impressions led one to expect; and some idea of the numerous woods and extensive moors is obtained. In the preparation of this vegetation map, the areas represented as wood, uncultivated land, and cultivated land respectively on the ordnance maps, form a

* Map, p. 484 . 
basis for the work; the limits of these are taken as correct unless observations on the spot show otherwise.

The vegetation of the area presents three subdivisions-

1. The Moorland.

2. The Woodland.

3. The Farmland.

\section{The Moorland.}

The political boundary between Yorkshire and Lancashire traverses the moorland throughout almost all this map; it therefore offers a convenient western limit. In order, however, to represent fully the characters of the vegetation, this limit has been taken far enough into Lancashire to show the falling slopes on that side of the Pennines. The highest altitudes of the moors are 1700 feet (515 metres) * on Boulsworth hill in the north-west, and 1909 feet (579 metres) on Black hill (Holme Moss) in the south. Thence the moors are almost continuous down to 1250 feet (380 metres), and in places descend to 900 feet (273 metres). The western part of the map is an extensive Millstone Grit plateau, dissected by numerous streams, which have cut their way through the surface rock, and formed deep narrow valleys, or "cloughs," in the shales below. In a few cases, the shales of the Pendleside or Yoredale series are reached at the bottom of these valleys. In the east, the Carboniferous Coal Measures overtop the gritstone rocks. Glacial clay is found on the moors west and north of Bradford, but is absent from the Calder-vale moors and southwards. The geology of the district is therefore very simple; and for ocological purposes, the area may be regarded as composed of hard rock and shale, both sandstone. The vegetation of the moorland is shown on the map under three primary divisions, each of which is easily recognized by its predominating colour when seen in mass: (1) the cotton-grass moor, greyish-green in early summer, and reddish-brown in autumn ; (2) the heather, brown in winter, and passing through a summer green to autumn purple; (3) the rough grass, green in summer and yellowish-brown in winter. The selection of these types of vegetation is based, however, not on mere ease of recognition, but on broader principles, namely, difference in soil, water-supply, and other conditions of environment, which will be dealt with more fully later.

Moss Moor.-The great part of the moors is dominated by the cottongrasses (Eriophorum vaginatum and E. angustifolium). The heather (Calluna) and the grass heaths are, as a rule, confined to the drier or steeper edges, or to isolated, outlying flanks and patches. The common cotton-grass ( $E$. vaginatum), with its associates, extends in monotonous tufts for miles, and in this latitude forms the backbone of " the backbone

* The altitudes are those given on the maps of the Ordnance Survey. 


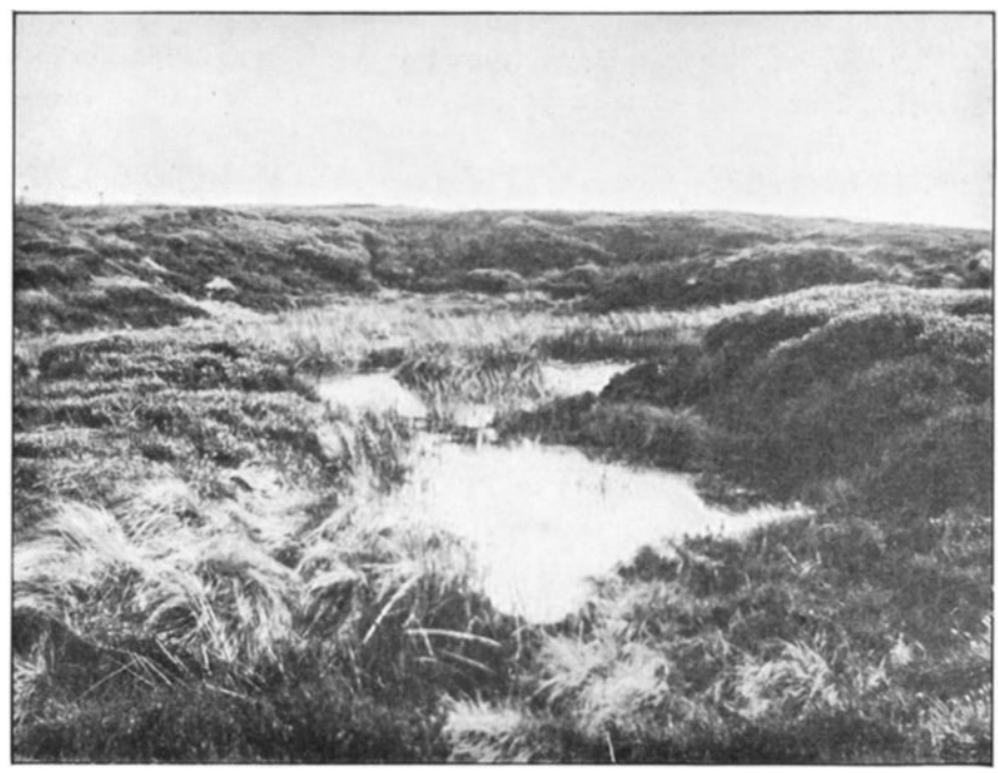

FIG. 1. On a Cotton-grass moor. The bog-tarn rests on clay at the base of the peat; the banks show the depth of peat. The background is the drier moor on deep peat.

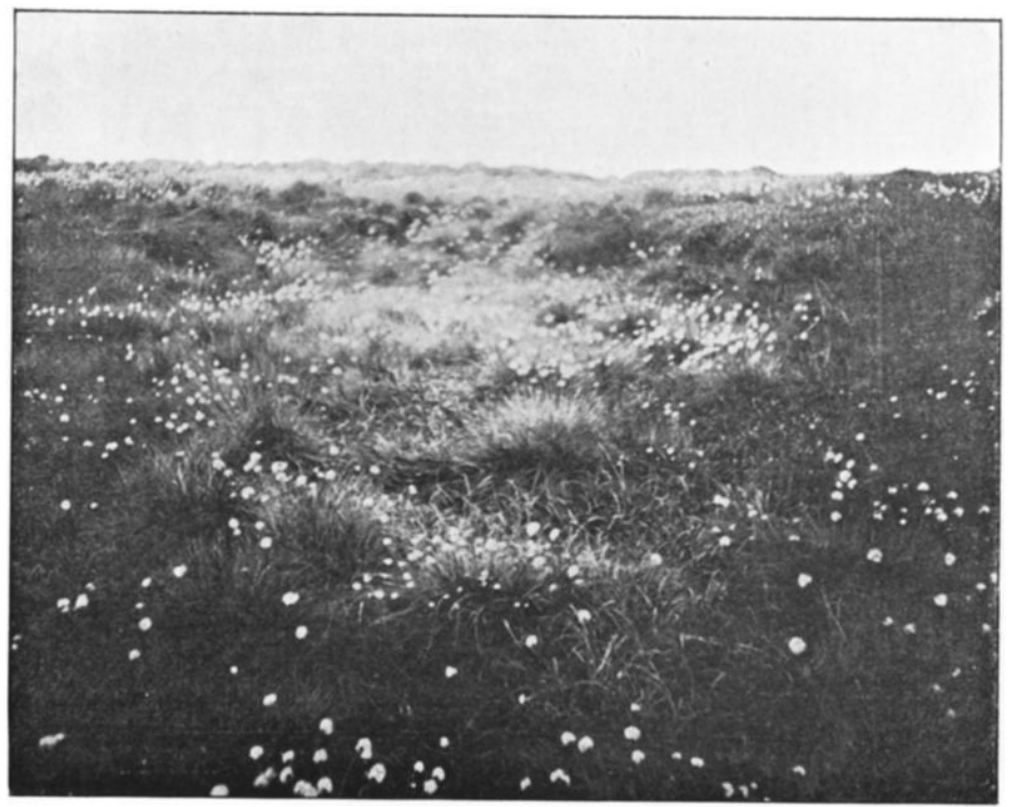

Fig. 2. Moss moor in June. Cotton-grass in fruit. 
of England" itself. The cotton-grass flourishes best on the almost flat moor summit, where the rainfall is great, the drainage bad, and the peat thick and permanently wet or damp (Fig. 1).* These moors are locally known as "mosses ;" and the vegetation of the area is extremely scanty in number of species. A few mosses and liverworts lie on the bare peat, a few species of algæ and lichens are not uncommon, now and then small fungi are seen, ferns are practically absent, and clubmosses are but rarely met with. The following are the flowering plants found in extreme cases of this Eriophorum association :-

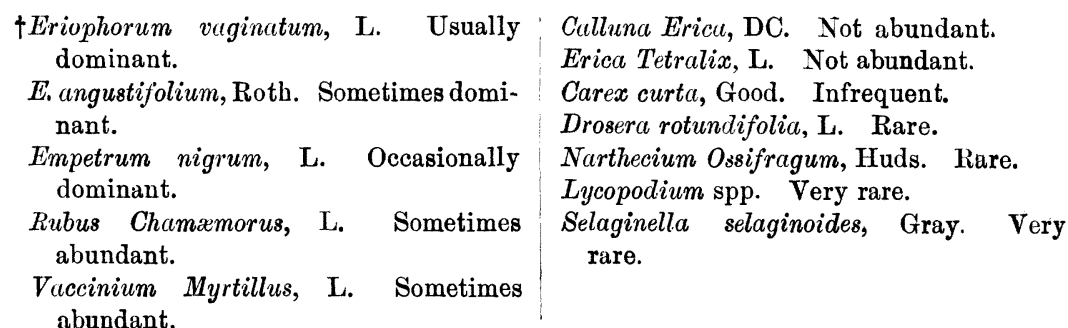

Such tracts are usually most monotonous in appearance. In autumn and winter, the reddish-brown leaves of the cotton-grass present a dreary aspect. Some life is infused into the area in early spring, when the dull florets make their appearance. In early summer the masses of white fruits form snow-like patches visible from a considerable distance (Fig. 2). The Eriophorum association is not extensively developed in Perthshire or Midlothian (1900), though R. Smith's unpublished maps show it to be of great extent in the west of Scotland. It is thus an association typical of the western region of Britain, and it seems probable that the association does not reach its maximum development with a rainfall of less than 40 inches $(100 \mathrm{cms}$.). The recording stations of the Halifax waterworks, situated in the Eriophorum area, indicate a mean annual rainfall of nearly 45 inches.

The Eriophorum moor is an example of the association known to German botanists as "Heidemoor" or "Moosmoor," and may be indicated by the English term "moss" or moss moor. The Sphagnum, or bog-moss, is regarded as an important element in the formation of the deep peat always found on the moss moor; yet in our area, while the peat is from 5 to 30 feet deep, Sphagnum beds are by no means conspicuous. The general impression received is that the peat is being gradually denuded or wasted; and this agrees with the conditions found in the neighbouring Kinderscout district of Derbyshire, as described by Sir E. Fry (1892).

On the bleak ridges of the upper moors the bilberry (Vaccinium

* The photographs for this paper were taken by Mr. W. B. Crump, M.A. (Halifax), who has generously placed them at our disposal.

$\dagger$ The nomenclature of the London Catalogue, 9 th edit., is followed throughout:

No. IV.-APrIL, 1903.] 
Myrtillus), a secondary social form of the Eriophorum and Calluna associations, becomes a rival for dominance; and in dry, rocky, windswept places it replaces the cotton-grass entirely. It has been considered advisable to record this type of vegetation on the map, because it has a connection with the Vaccinium slopes, recorded from 2000 feet upwards in Perthshire. Although the bilberry is nowhere so dominant or so extensively developed in the present map, the occurrence of the Vaccinium summit-ridge is characteristic (Fig. 3). It is not determined by altitude alone: its essential feature is that it forms the sky-limit of the moor, where it is exposed to all weathers. It is much drier than the "moss" below, more rocky, steeper, better drained, and the peat is shallower. The stations where this Vaccinium association occurs areHolme moss (1750 to 1900 feet), Boulsworth hill (1650 to 1700 feet), West Nab (1500 to 1640 feet), and to a smaller extent on other summits. The rocky edges of the various moors are also tenanted by much Vaccinium. The following plants are characteristic :-

Vaccinium Myrtillus, L. Dominant.

Empetrum nigrum, L. Often abundant.

Rubus Chamæmorus, L. Occasionally abundant.

Calluna Erica, DC. Common.

Rumex Acetosella, L. ,

Juncus squarrosus, L. , ,
Eriophorum vaginatum, I. Common.

E. angustifolium, Roth, "

Deschampsia flexuosa, Trin. ",

Festuca ovina, L.

Nardus strict $\iota, \mathbf{L}$.

Lycopodium spp. Rare.

The case of Black hill (Holme Moss) is exceptional, because vegetation is almost completely absent for fully half a square mile at the summit. The surface here consists of black, damp or slushy, decaying peat, with no emerging rocks. Almost the only vegetation is afforded by the creeping shoots of Eriophorum angustifolium, which bind together to some extent the loose peat.

The Eriophorum moor and the Vaccinium ridge represent types of vegetation where the influence of man is very slight, because both are unsuited either for grazing or game. In the former, wide ditches are occasionally constructed to encourage drainage and the consequent growth of bilberry and heather, plants better adapted to the habits of grouse than the Eriophorum. The marked scarcity of heather on the moss moor is not emphasized in any literature relating to the vegetation of this district; in fact, the impression is conveyed that heather is the dominant plant. Whether the area now occupied by Eriophorum was formerly covered with heather is a question difficult to answer; but vegetation maps such as the present will furnish in time to come a basis for comparison of this and other changes of flora.

Heath or Heather Moor.-The heather (Calluna), becomes dominant only on the edges of the moss moor or on detached patches (Fig. 4). The heather area in South-West Yorkshire is much more limited than that of Northern Perthshire or North-East Yorkshire. Peat is present 


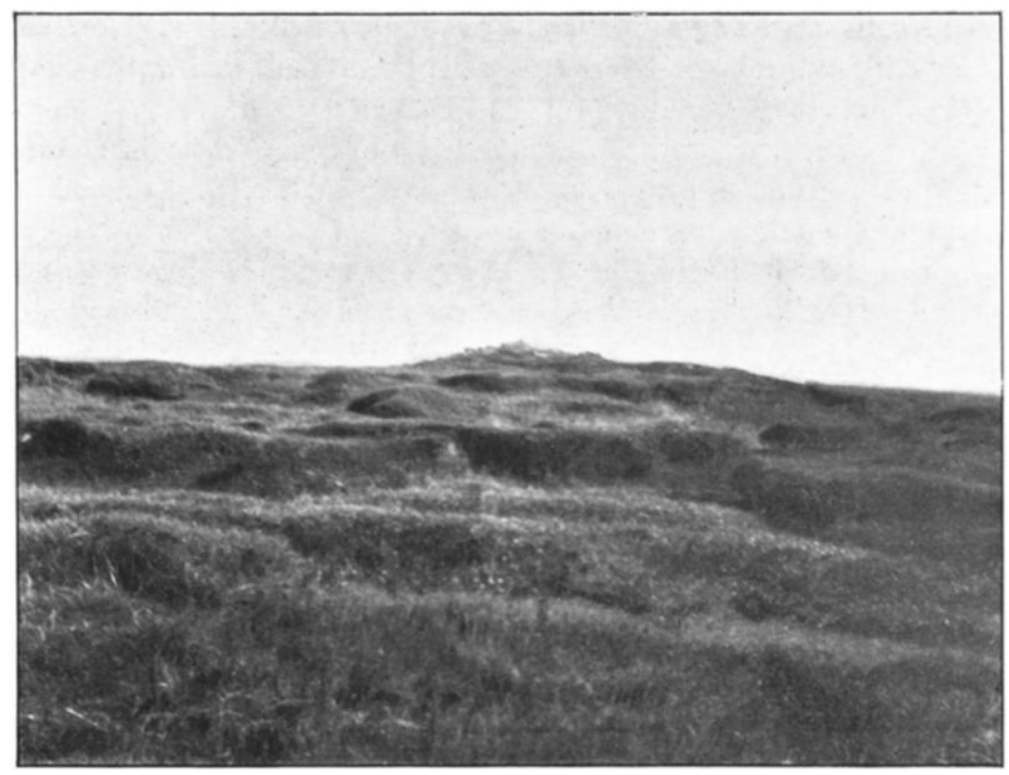

FIG. 3. Summit ridge of Boulsworth Hill. The vegetation is chiefly Vaccinium.

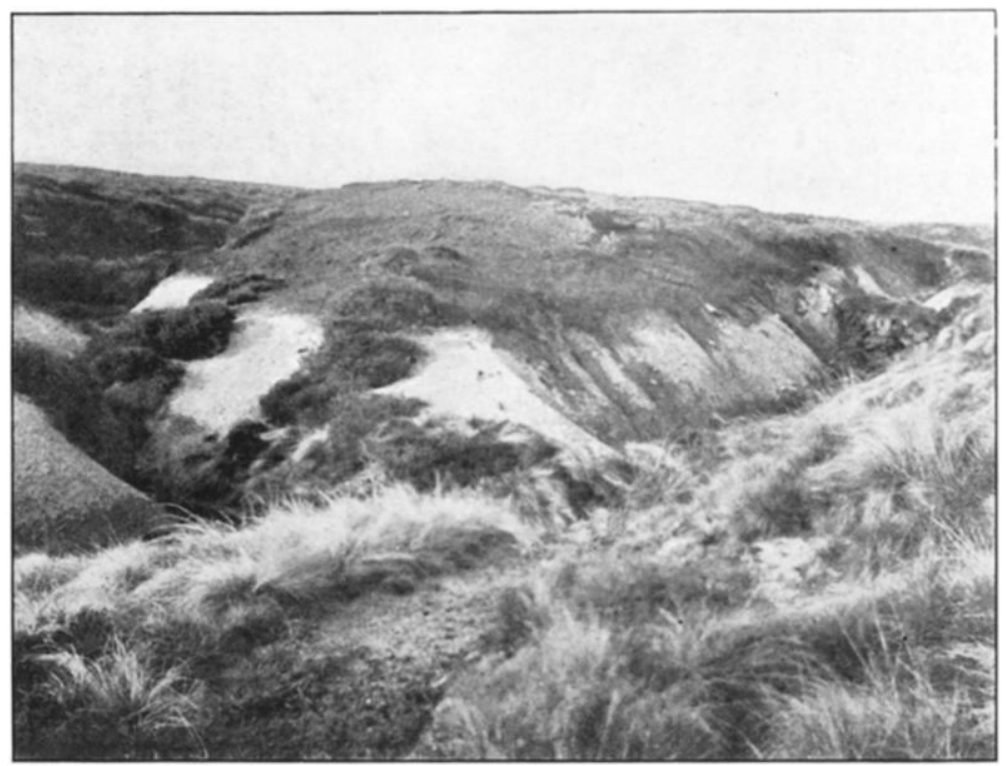

FIG. 4. Crimsworth Head. Edge of a cotton-grass moor, with dark patches of heather on the slopes and grasses near the stream. 
on the heath, varying from 3 or 4 feet in thickness to a few inches; whereas on the Eriophorum moor the peat is sometimes 30 feet thick. The heaths are flat, or nearly so; and steep shaly billsides are not heather-clad. The heather grows thickest and tallest in those places which are naturally well drained, and which are regularly and carefully fired by the keepers. The following plants are representative of the heather moor on the present map :-

Calluna Erica, DC. Dominant.

Ulex Gallii, Planch.

Genista anglica, L.

Potentill sylvestris, Neck.

Vaccinium Vitis-Idæa, L.

r. Myrtillus, L.

Erica cinerea, L.

Pyrola media, Sw. Rare.

Trientalis europxa, L. (one station).

Rumex Acetosella, L.

Orchis latifolia, L. Rare.
Luzula erecta, Desv.

Juncus squarrosus, $\mathrm{I}$.

Scirpus cxspitosus, L.

Carex Goodenowii, J. Gay.

C. flacca, Schreb.

C. panicea, L.

Agrostis vulguris, With.

Festuca ovina, $\mathrm{I}$.

Nardus stricta, L.

Lomuria Spicant, Desv.

Lastræa Oreopteris, Presl.

In wet places the following also occur:-

Erica Tetralix, L.

Ranunculus Lenormandi, F. Schl.

Irosera rotundifolia, $\mathrm{I}$.

Andromeda Polifolia, I. Rare.

Narthecium Ossifragum, Huds.

Juncus conglomeratus, L.
Potamogeton polygonifolius, Pour.

Carex echinata, Murr.

C. flava, $\mathrm{L}$.

Deschampsia cæspitosa, Beauv.

Molinia vari $\iota$, Schrank.

Sphagnum spp.

The heather vegetation, as will be seen, includes a greater variety of plants than that of the higher moors, and within itself presents several well-marked associations. Graebner, in a recent paper (1901), recognizes the heath or heather moor ("Calluna-heide") as a type of vegetation co-ordinate with the moss moor; but his description of the latter is confined to its occurrence at low altitudes only. He also recognizes as types "Tetralix-heide" and " Empetrum-heide," both of which are found in the present area. The Tetralix association forms a transition between our two types, occurring on the wet parts of the heath and on the margins of the moss moor; where well marked, it is shown by the letters "EH" on the Eriophorum moor colour. Graebner further subdivides his type into "Facies," most of which have been recognized in this survey, and in a more detailed scheme of colour could be represented.

Grassy Moorland.-The term "grass heath" (HPa) is here used to distinguish this vegetation from that which we call " natural pasture" (Pa). The latter is well developed on the moorland of the Mountain Limestone, and is characterized by a large number of plant-associates which do not belong to the heather vegetation. The grass heath, on the other hand, while dominated by grasses, includes many species already given as heath plants. The distinction thus made is recognized by 
continental botanists, who use the term " Gras-heide," while our natural pasture corresponds to their "Wiesen." The grass heath of the present area, like the Calluna heath, is always on the edge of the moor plateau. Two types of grass heath occur : one is flat or nearly so, wet, somewhat peaty, and dominated by Molinia (Fig. 5); while the other occurs on steep slopes, and is dry, almost without peat, and dominated by Nardus stricta, Deschampsia flexuosa, and Festuca ovina. The best example of the former is Erringden Moor : the latter is extensively developed on the shaly slopes around Todmorden. The following is a selected list from the Molinia association :---

Molinia vuriı, Schrank. Dominant.

Viola palustris, I.

Montia fontan, , L.

Lotus uliginosus, Schkuhr.

Hydrocotyle vulgaris, I.

Galium Witheringii (Sm.)

Vaccinium Myrtillus, L.

Schollera Occycoccus, Roth.

Calluna Erica, DC.

Erica Tetralix, I.

Narthecium Ossifragum, Huds.
Juncus squarrosus, I.

$J$. conglomeratus, $\mathrm{I}$.

Luzula erect $\iota$, Desv.

Carex echinata, Murr.

C. flacca, Schreb.

C. flava, I.

C. Goodenowii, Gay.

C. binervis, $\mathrm{Sm}$.

Deschampsia flexuosa, 'Irin.

Nardus stricta, I.

The dry grass heath occurs on the steep hill-slopes; and for this reason, probably, there is no peat. It is better suited for pasturage than the wet grass heath. The following species are represented :-

Festuca ovina, L.) One or both

Nardus strica, L. $\}$ dominant.

Deschampsia flexuosa, Trin.

Aira præcox, $\mathrm{L}$.

Sieglingia decumbens, Bernl.

Agrostis vulgaris, With.

Viola lutea, Huds. Isocal.

Genista anglica, 1. Not common.

Ulex Gallii, Planch.

Potentilla sylvestris, Neck.

Galium saxatile, L.

Vaccinium Myrtillus, L.
Calluna Erica, DC.

Evica cinerea, I.

Rumex Acetosella, I.

Orchis maculata, $\mathrm{L}$.

Luzula erecta, Desv.

Carex pulicaris, I. Not common.

C. pilulifera, $\mathrm{I}$.

C. binervis, $\mathrm{Sm}$.

Pteris aquilina, L.

Lomaria Spicant, Desv.

Lastræa Oreopteris, Presl.

On the whole, the grass heaths of this part of Yorkshire are limited in extent compared with North Yorkshire and Scotland. They also show fewer species, and are deficient in plants indicating good soils.

At the upper limit of cultivation many farms are derelict, or rapidly becoming so. Some of the pastures here are quite heathy in character, and are said by the farmers to be "running back to moor." The pastures furnish a connecting link between the heaths and the area of cultivation. They possess a rich and varied flora, many local rarities being found there. In addition to the heaths and grasses of the heaths, the fullowing occur :- 


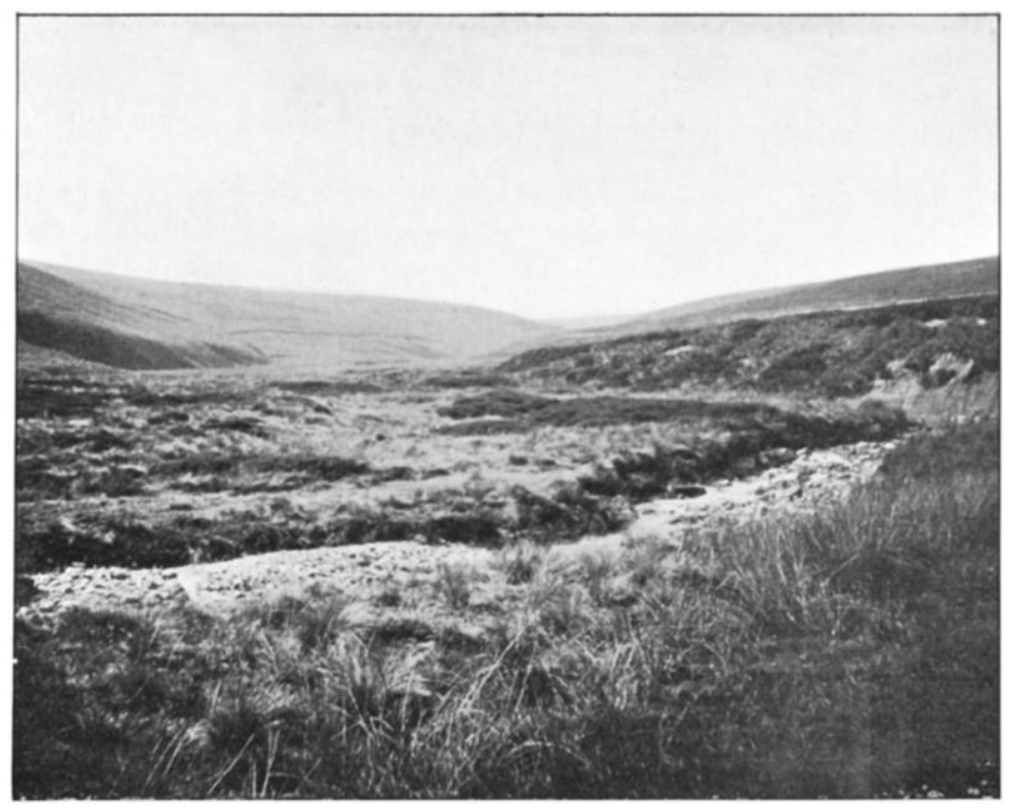

Frg. 5. Walshaw Dean. Grass heath in the moorland valley of a stream. Cotton-grass moors on distant heights.

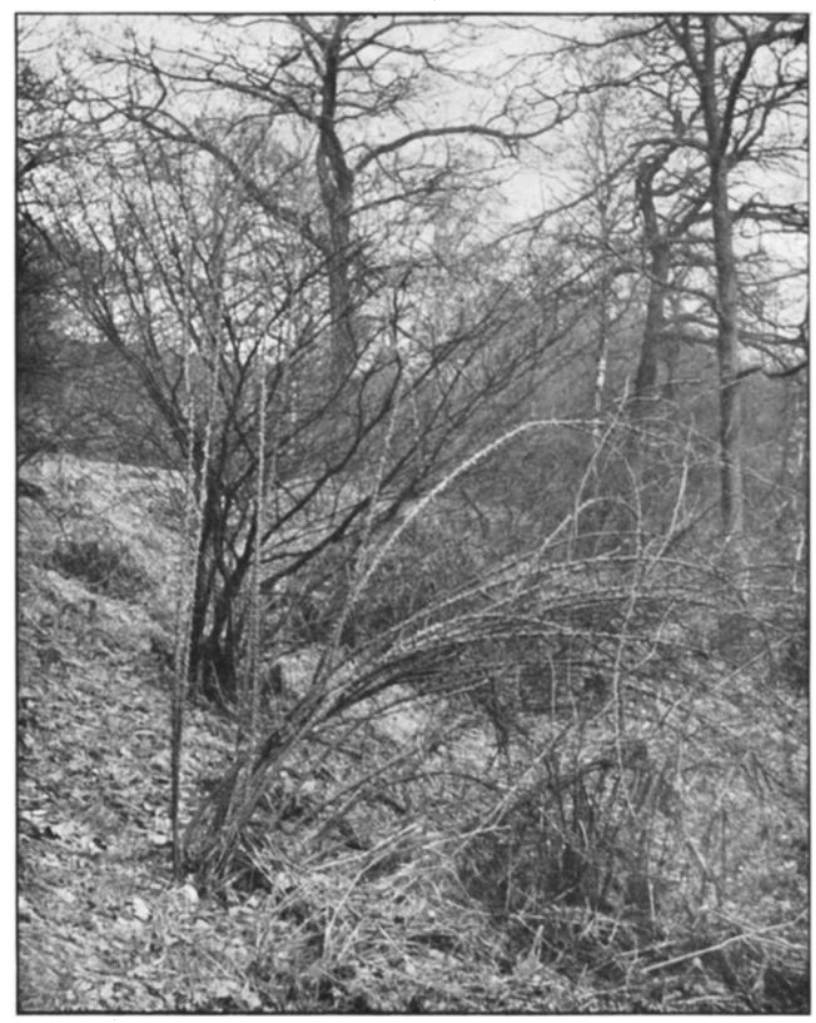

FIG. 6. The Undergrowth of an open oak wood. 
Viola lutea, Huds. Local.

Hypericum pulchrum, I.

H. quadratum, Stokes.

Linum cartharticum, L.

Ulex Gallii, Planch.

Cytisus scoparius, Link.

Cratrgus Oxyacantha, L.

Antennaria dioica, R. Br. Rare.

Gnaphalium sylvaticum, I. Rare.

Taraxacum palustre, DC.

Wahlenbergia hederacea, Reichb.

Rare.

Erythræa Centaurium, Pers. Not common.

Gentiana Amarella, L.

Digitalis purpurea, $\mathrm{I}$.
Euphrasia officinalis, I.

Thymus Serpyllum, Fr. Rare.

Teucrium Scorodonia, L.

Betula pubescens, Ehrh. (dwarfed).

Quercus Robur, I. (dwarfed).

Salix aurita, $\mathrm{L}$.

Habenaria conopsea, Benth.

H. bifolia, R. Br.

H. viridis, R. Br. Not common.

Luzula erecta, Desv.

Carex, spp.

Briza media, L.

Ophioglossum vilgatum, I.

Botrychium Lunaria, Sw.

The relations of the foregoing moorland associations may be briefly summarized thus :

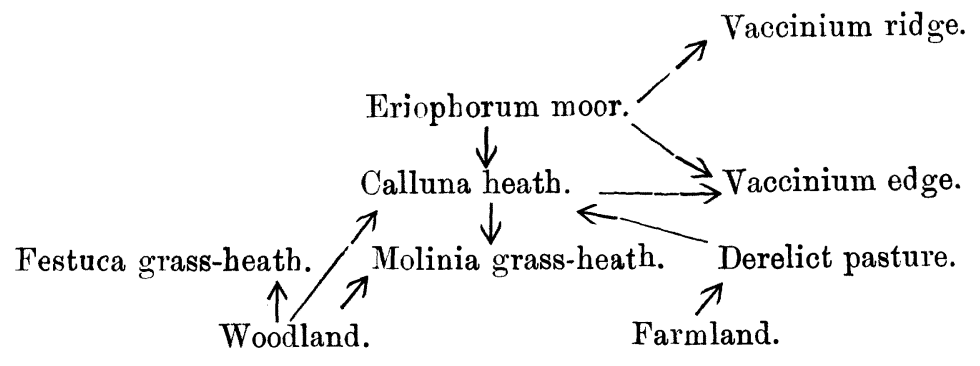

This table also furnishes some idea of the development of the various types of moorland. The Eriophorum moor passes upwards into the Vaccinium ridge and downwards into the Vaccinium edge and Calluna heath. It is also noteworthy that the Calluna heaths are all within the present altitudinal range of woodland, and remains of treetrunks are occasionally found embedded in the peat. Amongst workers in North-West Germany, it is generally acknowledged that much of the heath area has been derived from former forest (Smith, W. G., 1902B). Whether the great stretches of Eriophorum moor have in post-glacial times been tree-clad is uncertain. The grass heaths are all of the heath type; but the Molinia type shows this relationship better than the Festuca heath. The latter, being on steep, shaly hillsides, was probably never covered with peat at all. It is possible that much of the grass heath was once wooded, and in a forest map would be shown in the upper oak forest zone. The heath and hill-pasture abut on the area of cultivation; and the upper farms have been enclosed from these, leaving a ragged fringe of moorland which has never been brought under the plough, either because too steep or too rocky. By selection, certain portions might profitably be converted into farmland; while it appears certain that good forestry would convert nearly all of these places into woodland. 


\section{The Woodland.}

Woods occur from the edge of the moorland plateau down to sealevel. Throughout the whole area the oak is the dominant tree. In Flahault's vegetation survey of the south of France, ten types of forest are represented. In R. Smith's Scottish survey there are five, namely, oak, birch, pine, larch, and mixed lowland deciduous. In the present map, only three of these are considered worthy of special colours, namely, oak, mixed lowland (with beech), and pine. The birch wood or uppermost tree zone of the Scottish highlands is represented in the West Riding by a modification of the oak wood. Larch woods, so characteristic of the Scottish moorlands, are here quite subordinate, and included under pine woods. In the present paper the oak woods alone will be dealt with, the consideration of pine woods being deferred. The beech wood, so typical of Central Europe, is not well represented in South-West Yorkshire, except on or near the Permian tract. Beech is not uncommon, but its occurrence in parklands, or as small detached plantations, suggests artificial planting; and it seems best to consider it as an introduction into the oak wood. The woods where beech and other lowland deciduous trees outnumber the oak, are indicated on the map, because the presence of these trees tends to alter the whole character of the vegetation growing beneath; and where beech is present in quantity the association approaches that of the typical beech forest (Figs. 6 and 7).

Before considering the botanical features of the woodland, the topographical features of this area are of interest. The orographical maps of the ordnance survey, or those recently issued by Messrs. Bartholomew, show that the western or moorland area of the map is an almost continuous plateau, ranging from about 1250 feet upwards. The middle portion of the map consists of valleys and intervening uplands, sloping from the plateau downwards to the lowlands or eastern part of the map. Accompanying the general lowering of altitude from west to east, there is a decrease in the annual rainfall (see p. 396). The geology also changes with the decreasing altitude; and the western Millstone Grit gives place to the Coal Measures as surface rocks. This boundary is approximately indicated on our map by the places Hepworth, Huddersfield (west side), Stainland, Elland, Halifax (east side), Ogden, and Leeming; thence it turns eastward, passing near Shipley, Calverley, Kirkstall, and Roundhay (Leeds), and under the Permian near Barwick-in-Elmet. The Permian series occurs in the extreme east of this map, the boundary between it and the Coal Measures passing southwards from Garforth to Pontefract and Hickleton. The contour of the woods on our map offers a ready but fairly accurate means of distinguishing the Millstone Grit from the Coal Measure area. In the former the valleys are narrow with steep sides, and the woods 


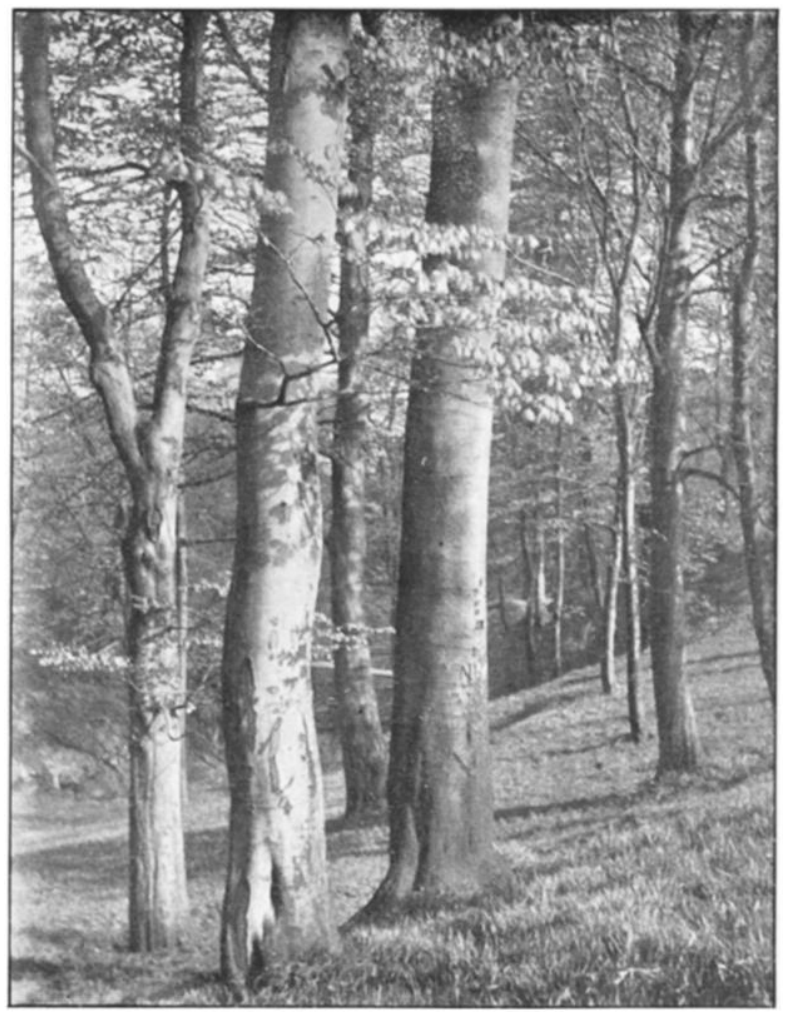

FIG. 7. The effect of Beech on the undergrowth. 
appear as narrow strips; in the latter the valleys are broad with gentle slopes, and the woods in consequence appear broader and rounded.

OAK WooDs.-In the narrow western valleys the woods usually occur on the slopes and rarely rise to the open upland. As the valleys widen out on the Coal Measures, the oak woods are still mainly confined to the valleys, but emerge more from them. Three types of oak wood are recognized-

1. Clough Thicket or Wood.

2. Upland Oak Wood.

3. Lowland Oak Wood.

The lowland oak wood occurs below about 500 feet (152 metres). The dry oak wood occurs chiefly above this altitude, and extends upwards to 800 or 1000 feet, where it merges into the clough wood.

The Clough.-The moorland plateau of Millstone Grit finishes in a precipitous edge; and the waters from the moor, gathered into narrow but well-marked streams, descend abruptly over this edge; excavating it backwards and downwards to form a gorge, with a steep head and steep rocky slopes littered with weathering sandstones and shales. These gorges are locally known as " cloughs." The abrupt change in altitude and environment is at once perceptible in the vegetation, which changes rapidly from that of the moor edge to a loose thicket of shrubs and low trees, in many respects stamped with the characteristics of a wood. A useful account of the geology and natural history of Norland Clough is given in a series of papers in the Halifax Naturalist (1900). The typical clough is not crowded with tree vegetation; but trees and shrubs are abundant enough to form a loose thicket or scrub, sometimes dense enough to be regarded as a wood of the next class (Fig. 8). The following constitute the scrub of the clough :-

\begin{tabular}{l|l|l} 
Oak. & Blackthorn. & Rose. \\
Birch. & Bird-cherry. & Bilberry. \\
Mountain Ash. & Willows (threc spp.). & Ling. \\
Holly. & Honeysuckle. & Heaths (two spp.). \\
Hawthorn. & Bramble. & Ulex Gallii, Planch.
\end{tabular}

The arrangement of these elements varies from place to place. Here the taller trees and shrubs may be thickly clustered, there gorse; in other parts bilberry, heather, or bracken covers the ground. The herbaceous vegetation of the drier parts includes-

Violı Riviniana, Reich. Polygala serpyllacea, Weihe. Hypericum pulchvum, I. Potentilla sylvestris, Neck. Alchemilla vulgaris, $\mathrm{L}$. Pimpinella Saxifragı, L. Galium saxatile, I. Scribiosa Succisa, T. Solidago Virgaurea, L. Gnaphalium sylvaticum, L. Centaurea nigra, I.
Hieracium Pilosella, L.

H. vulgatum, Fries.

Jasione montana, $\mathrm{I}$.

Campanula rotundifolia, L.

Vaccinium Myrtillus, I.

Calluna Erica, DC:

Erica cinerea, L.

P'yrola media, Sw. Rare.

Digitalis purpurea, L.

Teurrium Scorodonia, L.

Rumex Acetosella, I.
Orchis maculata, $\mathrm{L}$.

Habenaria conopsea, Benth. Luzula campestris, DC.

Luzula erecta, Desv.

Carex pilulifera, L.

Agrostis vulgaris, With. Sieglingia decumbens, Bernh.

Festuca ovina, L.

Pteris aquilina, $\mathrm{I}$.

Lomaria Spicant, Desv.

Lastræa Oreopteris, Presl. 
Clough Swamp.-Parts of the clough are wet, and support a larger number of moisture-loving plants than the upper moorland :-

Ranunculus Lenormandi,
$\quad$ F. Schultz.
R. Flammula, L.
Viola palustris, I.
Lychnis Flos-cuculi, L.
Stellaria uliginosa, Murr.
Montia fontana, I.
Hypericum quadratum,Stok.
Lotus uliginosus, Schk.
Spiræa Dlmaria, L.
Drosera rotundifolia, L.
Callitriche stagnalis, Scop.
Hydrocotyle vulgaris, I.
Enanthe crocata, I.
Galium Witheringii (Sm.).
Achillea Ptarmica, I.
Senecio aquaticus, Huds.

\begin{tabular}{|l|l} 
Cnicus palustris, Willd. & Potamogeton polygonifolius, \\
Crepis paludosa, Moench. & Pour. \\
Lysimachia nemorum, I. & Scirpus setaceus, L. \\
Myosotis cæspitosa, F.Sch. & Carex echinata, Murr. \\
M. palustris, Relh. & C. Goodenowii, J. Gay. \\
M. repens, G. Don. & C. lævigata, Sm. \\
Veronica Beccabunga, I. & C. pendula, Huds. Rare. \\
Pinguicula vulgaris, L. & C. binervis, Sm. \\
Scutellaria minor, Huds. & C. fulva, Good. Rare. \\
Rare. & C. flava, L. (var.). \\
Orchis latifolia, L. & Agrostis palustris, Huds. \\
Narthecium Ossifragum, & Deschampsia cæspitosa, \\
Huds. & Beauv. \\
Juncus conglomeratus, I. & Holcus lanatus, I. \\
J. lampocarpus, Ehrh. & Equisetum limosum, Sm. \\
J. acutifolius, Ehrh. & E. palustre, L.
\end{tabular}

Mosses, hepaticæ, and algæ are well represented.

Upland Oak Woods.-These extend from 500 feet to 1000 feet (152 to 300 metres). They occupy dry rocky slopes on the Millstone Grit area. The oak is usually dominant; but when the best of these trees are removed and no others planted, the birch becomes dominant, either alone or mixed with stunted oaks. There is reason to believe that before the expansion of the cultivated land to its present limits, the upland oak wood must have formed a well-marked zone of primitive forest, following the course of the valleys; but as disforesting has gone on without much attempt at replanting, the existing woods are only the meagre remains of this. Where replanting has been attempted, mixed plantations may occur on the site of the previous oak woods. In such cases the Scots and Austrian pines, spruce, larch (occasionally), sycamore, and beech are found in varying proportions; and all (except perhaps the larch) do well if suitable precautions are taken.

The loose canopy of the oak wood favours a thick undergrowth (Fig. 6), which, however, does not include a large number of species. This undergrowth may form a loose thicket of small shrubs. In less shaded parts the bilberry or bracken or grasses become dominant; while the rocky edges and open parts are not uncommonly covered with heather and some of its associates.

Lowland Oak Woods.-This name is given to what might equally well be called damp oak woods, or mixed deciduous woods. On the Millstone Grit, woods of this type are confined to the valley bottoms below an altitude of about 500 feet; but throughout the wider valleys and lower altitudes of the Coal Measures they are of greater extent. The woods seen in traversing the area by railway are usually of this kind. The oak is still a dominant tree, though the sycamore and 


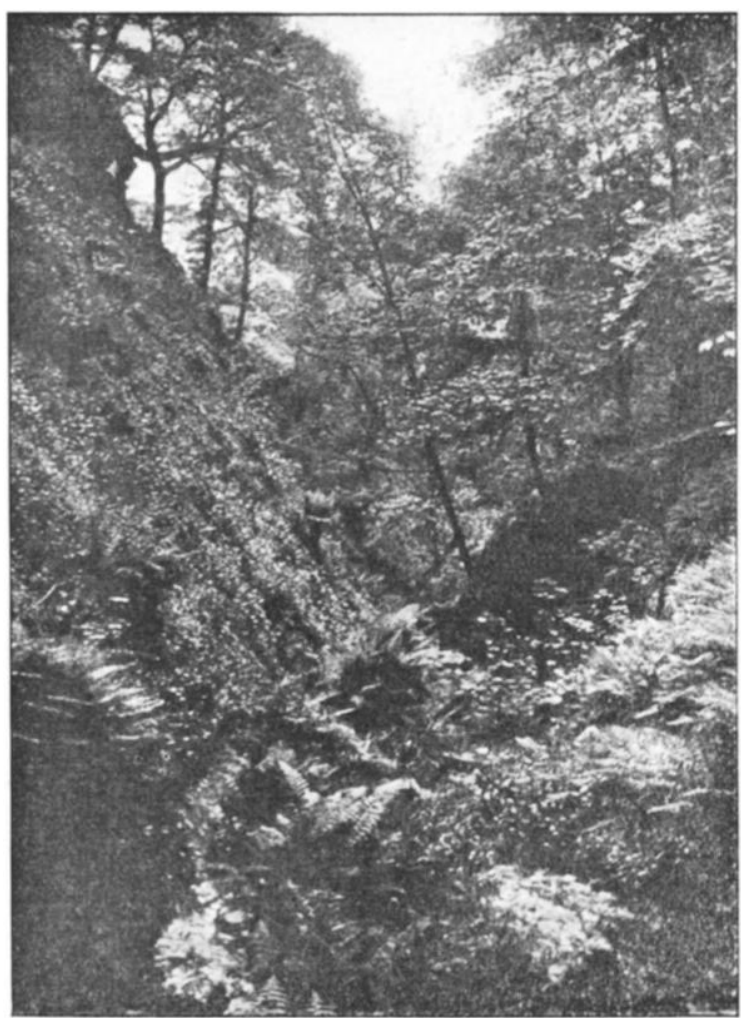

FIG. 8. Oak wood; in the Clough. 
wych elm frequently share dominance. Ash, beech, and alder are less common, but still frequent; while horse-chestnut, sweet chestnut, poplars, the larger willows, and conifers, are occasionally planted. The best development of these oak woods occurs in the Dearne district around Barnsley.

The upland oak wood is usually dry and rocky, and deficient in humus: the lowland oak wood is damp, shaly, and richer in humus. The shade cast by the trees is much greater in the latter than in the former. Hence the flora of the latter is much richer in species, especially of the bulbous and early flowering kinds; while the flora of the upland oak wood contains a high proportion of late-flowering, moorland xerophytes, which are practically absent from the lowland oak wood. This difference is also observable in regard to mosses and liverworts. In order to facilitate comparison, the following full, but not exhaustive, lists are placed side by side :-

\section{UPLAND OAK WOOD. Trees.}

Quercus Robur, I.

Betula pubescens, Ehrh. Pyrus Aucuparia, Ehrh. Cratægus Oxyacantha, I.

Shrubby Forms.

Ilex Aquifolium, I. Corylus Avellana, I. Prunus spinosa, I.

P. Padus, I.

Rubus Lindleianus, Lees. R. radula, Weihe.

Rosa canina, I.

Hedera Helix, L.

Lonicera Periclymenum, I. Vaccinium Myrtillus, $\mathrm{T}$.

Calluna Erica, DC.

Salix aurita, I.

S. Caprea, I.

S. repens, L. Rare.

Herbaceous or Ground Forms.

Neckeria claviculata, N.E.Br.

Lychnis dioica, L.

Hypericum pulchrum, L. Lathyrus montanus, Bernh. Potentilla sylvestris, Neck. Epilobium angustifolium, L. Galium saxatile, L. Solidago Virgaurea, L. Hieracium vulgatum, St.

LOWLAND OAK WOOD.

Trees.

Quercus Robur, I.

Betula pubescens, Ehrh.

B. verrucosa, Ehrh.

Fagus sylvatica, L.

Acer Pseudoplatanus, I.

Fraxinus excelsior, $\mathrm{T}_{\text {. }}$.

Shrubby Forms.

Ilex Aquifolium, I.

Corylus Avellana, I.

Acer campestre, $\mathrm{I}$.

Ulex europæus, L.

Rubus idæus, L.

$R$. Sprengelii, Weihe.

Rosa arvensis, Huds.
Ulmus montana, Stokes.

Prunus Avium, $\mathrm{I}$.

P. Cerasus, L.

Cratægus Oxyacantha, I.

Alnus glutinosa, Medic.

Salix fragilis, I.

\section{Hedera Helix, L.}

Lonicera Periclymenum, L.

Sambucus nigra, $\mathbf{I}$.

Viburnum Opulus, I.

Solanum Dulcamara, I,

Salix Caprea, I.
Herbaceous or Ground Forms.

Anemone nemorosa, $\mathrm{I}$.

Ranunculus repens, L.

R. Ficaria, L.

Caltha palustris, $\mathrm{L}$.

Trollius europæus, L. Iocal. Cardamine pratensis, $\mathrm{I}$.

C. amara, $\mathrm{L}$.

C. flexuosa, With.

Viola Riviniana, Reich.

Lychnis dioica, $\mathrm{I}_{4}$.
Veronica Chamædrys, L.

V. montana, L.

Lathraa Squamaria, I.

Nepeta Glechoma, Benth.

Stachys Betonica, Benth.

S. sylvatica, L.

Galeopsis Tetrahit, I.

Lamium Galeobdolon, Cran.

Ajuga reptans, L.

Polygonum Bistorta, $\mathrm{I}_{4}$. 
Herbaceous or Ground Forms.

Jasione montana, I. Campanula rotundifolia, L. Pyrola media, $\mathrm{Sw}$. Rare. P. minor, I. Rare.

Digitalis purpurea, $\mathrm{I}_{\text {. }}$.

Melampyrum montanum, Johnst.

Teucrium Scorodonia, I.

Rumex Acetosella, L.

Luzula erecta, Desv.

Carex pilulifera, I.

Agrostis vulgaris, With.

Deschampsia flexucsa, Tr.

Holcus mollis, I.

Molinia varia, Schrank.

Melica uniflora, Retz.

Nardus stricta, $\mathrm{I}_{\text {. }}$

Pteris aquilina, L.

Lomaria Spicant, Desv.

Lastræa Oreopteris, Pres1.

L. Filix-mas, Presl.

L. paleacea, Moore.

L. dilatata, Presl.

\section{Herbaceous or Ground Forms.}

Stellaria nemorum, $\mathrm{I}_{1}$. Local.

S. Holostea, L.

Arenaria trinervia, $\mathrm{I}$.

Geranium sylvaticum, $\mathrm{I}$.

G. Robertianum, L.

Oxalis Acetosella, L.

Vicia sylvatica, I. Local.

V. sepium, L.

Spiræa Ulmaria, I.

Geum urbanum, I.

G. rivale, $\mathrm{L}$.

Fragaria vesca, I.

Potentilla Fragariastrum, Ehrh.

Chrysosplenium oppositifolium, $\mathbf{L}$.

C.alternifolium, I. Local.

Circza lutetiana, L.

Sanicula europæa, I.

Conopodium denudatum, Koch.

Myrrhis Odorata, Scop.

Chærophyllum temulum, I.

Angelica sylvestris, I.

Heracleum Sphondylium, I.

Caucalis Anthriscus, Huds.

Galium Aparine, I.

Asperula odorata, L.

Valeriana sambucifolia, Willd.

$V$. dioica, L. Local.

Tussilago Farfara, I.

Petasites officinalis, Moench.

Arctium minus, Bernh.

Cnicus heterophyllus, Willd.

Rare.

Lapsana communis, L.

Crepis paludosa, Moench.

Lactuca muralis, Fres.

Campanula latifolia, I. Rare.

Primula acaulis, L.

Lysimachia nemorum, $\mathrm{I}$.

Myosotis palustris, Relh.

M. sylvatica, Hoffm.

Beauv.
Rumex viridis, Sibth.

R. Acetosa, $\mathrm{L}$.

Mercurialis perennis, L.

Urtica dioica, $\mathrm{L}$

Neottia Nidus-avis, Rich.

Rare.

Epipactis latifolia, All.

Local.

Orchis mascula, $\mathrm{T}$.

Narcissus Pseudo-narcissus, I.

Tamus communis, $\mathrm{I}$.

Allium ursinum, $\mathrm{L}$.

Scilla festalis, Sal.

Gagea fascicularis, Sal. Local.

Paris quadrifolia, L.

Juncus effusus, I.

Luzula vernalis, DC.

L. maxima, $\mathrm{DC}$.

Carex remota, $\mathrm{L}$.

C. pendula, Huds. Local.

C. sylvatica, Huds. Local.

C. lævigata, $\mathrm{Sm}$.

Anthoxanthum odoratum, L.

Milium effusum, I.

Deschampsia cxspitosa,

Melica uniflora, Retz.

Poa nemoralis, L. Rare.

P. pratensis, $\mathbf{L}$.

Festuca sylvatica,Vill. Rare.

Bromus giganteus, L.

B. ramosus, Huds.

Brachypodium gracile, Beauv.

Athyrium Filix-fomina, Roth.

Iastræa Filix-mas, Presl.

I. spinulos $\alpha$, Presl.

L. dilatata, Presl.

Phegopteris Dryopteris,

Fee. Rare.

P. polypodioides, Fee.

Local.

Equisetum sylvaticum, L.

\section{The Farmland, or Area of Cultivation.}

This, with the woodland, includes all vegetation up to the limit of cultivation, and corresponds to H. C. Watson's Agrarian region. It is situated below 1250 feet ( 380 metres), except small isolated patches which occur up to nearly 1500 feet. On a reconstruction map like Flahault's, the greater part of the farmland would be regarded as enclosed from 
the primitive forest, and included under one of the types of oak wood. Apart from the woodland, this area presents two distinct sub-types of vegetation-(1) uncultivated lands; (2) cultivated lands.

(1) UNCULTIVATED LANDS.- The area of cultivation has occasional patches of land which, never cultivated, have remained more or less primitive in character. Some of these are steep, rocky, or badly drained places belonging to the moor edge, unsuited for ploughing, and left island-like in the midst of cultivation; others are common grazinggrounds belonging to villages; others are wood-clearings never brought under the plough. Places of this kind deserve attention in a survey, because they give some evidence of the primitive vegetation of the district before agriculture displaced it. At the same time, human influences have affected them; they are generally used as grazinggrounds and are readily accessible to the plant-collector, hence too much weight cannot be laid on the evidence they offer. When of sufficient size to show on a map of this scale, the dominant vegetation of these areas is indicated by the colours used for grass, or heather, or mixtures of grass and heather. A special colour has been used to indicate lowland swamps with aquatic vegetation. In considering the uncultivated lands, we shall take them in the order of the geological areas, from west to east.

A. Dry Heaths of the Millstone Grit Area.-The uncultivated parts near the moorland may be recognized at once as vestiges of the primitive moor. The vegetation agrees closely with that already given as characteristic of grassy or heathery moor-edge. Away from the moorland, the heaths represent wood clearings, or a series of them may be correlated as remains of a larger moor or heath broken up by cultivation. An example of the latter occurs in the north-west corner of this map. It extends between the Wharfe and the Aire, from Otley Chevin south to Yeadon and east to Shadwell, near Leeds; it is a plateau of 800 feet altitude, declining southwards and eastwards to 500 feet. This area represents a former moor or moors known as Guiseley and Yeadon Moors, and Adel or Black Moor, a considerable tract of land which is now almost entirely under cultivation, and where wheat is grown up to 650 feet. Guiseley Moor now exists as a strip of heather vegetation along a road-bank above Otley Chevin, and as the warrens and coverts on the Chevin itself. The Black Moor at Adel extends from Meanwood Beck eastwards to near Wyke, Shadwell, and Roundhay, and on this area one may, within easy distance of Leeds, find several remnant patches of heath regetation. The heath near Adel is shown by earlier lists of plants to have included almost all the species met with in the moor-edge vegetation; although at the present day only the common and more abundant remain, including three heaths, bilberry, gorse, and birch. These relics indicate the eastern end of a chain of moors of which the links, Rumbolds Moor and Barden Moor, are still wild 
in character, and lead up to the Pennine mass of moorland. East of Adel, outliers of the Permian appear, and Calluna disappears. The most easterly occurrence of Calluna was found on the south side of Bramham Park, in the Permian area, but the Calluna itself is on an inlier of Millstone Grit.

The heaths found at lower altitudes are generally drained by streams whose banks support a vegetation which shows affinities with the clough swamp, the upper and lower oak zones, and the lowland swamp vegetation. The valley of the Meanwood Beck above Leeds may be taken as an example. The stream rises near Bramhope (600 feet) on what has been a moor, but is now farmland. At Adel Dam (400 feet) an artificial reservoir has become a swamp in which plants of the clough swamp and wet heath may be found with species of the lowland swamp. The stream from this place, till it enters the Coal Measures (about 200 feet), flows through a valley the banks of which present in succession grass heath with gorse and bracken; heath with heather, ericas, bilberry, and other associates; birch wood; alder and willow thicket; or oak woods more or less altered by introduced trees. Thus within a short excursion, almost all the types of the present map may be seen occupying limited areas. Mr. Lees (1880) gives a list of a hundred species in Meanwood valley, and this includes neither common plants nor many agricultural weeds which have become established. A zone of intermediate marsh vegetation is thus presented, and the following plants are characteristic. Some of them are found in the clough swamp, and almost all occur in the lowland aquatic vegetation.

Intermediate zone of marsh-

Nasturtium palustre, DC.

Cardamine amara, $\mathrm{L}$.

C. pratensiz, L.

Hypericum quadratum, Stokes.

Epilobium hirsutum, L.

E. obscurum, Schreb.

Hydrocotyle vulgaris, $\mathrm{L}$.

Apium nodiflorum, Reichb.

Enanthe crocata, $\mathrm{L}$.

Galium Witheringi (Sm.).

Valeriana dioica, L.

Scrophularia nodosa, L.
Scutellaria galericulata, L.

Polygonum Hydropiper, L.

Polygonum amphibium, $\mathrm{L}$.

Elodea canadensis, Michx.

Sparganium ramosum, Huds.

Lemna minor, $\mathrm{L}$.

Alisma Plantago-aquatica, L.

Triglochin palustre, L.

Eleocharis palustris, R. Br.

Carex remota, $\mathrm{L}$.

Phalaris arundinacea, L.

Equisetum palustre, L.

B. The Coal Measure Common.-This bears a strong resemblance to the Millstone Grit heath just described, and is quite distinct from the Permian common. It is as a rule distinguished by the rare occurrence of the plants of the Calluna heath, which are so frequent on the grit. Brierley Common, between Hemsworth and Cudworth, is the largest area of this kind, and other examples occur on the watersheds of the tributaries of the Dearne and Calder. The following list was taken 
in July on Netherton Common, south of Wakefield, and shows the plants characteristic of such commons:-
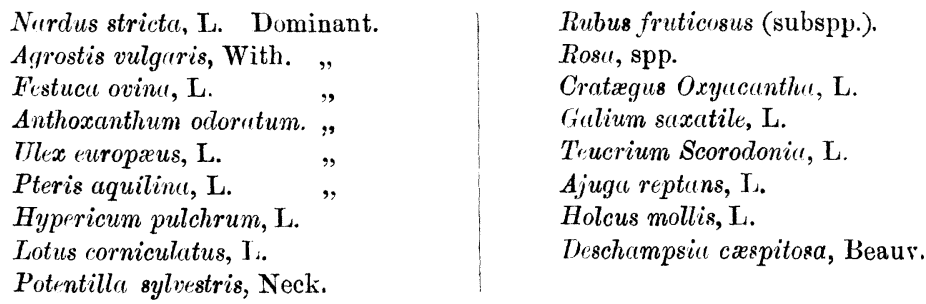

The hill known as Baildon common (927 feet), near Shipley, is another example. It is an outlier of the lower Coal Measures in the Millstone Grit. Its general grassy aspect at once distinguishes it from the dark heathery edges of Rumbolds moor, 2 miles off ; a closer examination showed that it agrees with the list just given.

C. The Permian Common.-The Permian area is so much under cultivation that few uncultivated places are left. Disused quarries are common, and afford a refuge for a varied flora, generally with the character of a copse or thicket of ash and hazel. It is advisable to defer the description of the limestone vegetation till the next map of this series. On the present map, however, Hook Moor, near Aberford, is the best example of a primitive Permian grass moor met with in the survey of the West Riding. The vegetation is so different from any of the grass heaths already described that it is noteworthy :-
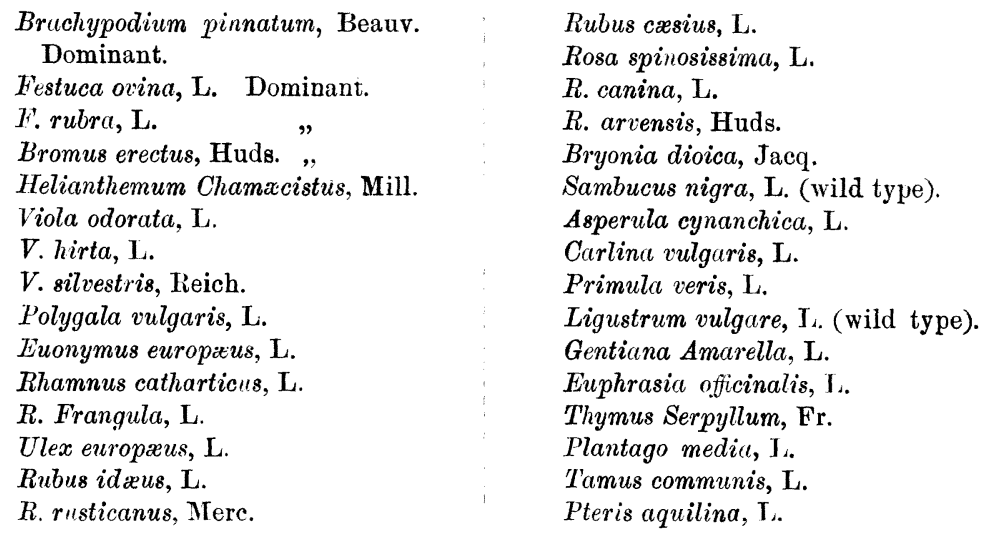

The character of this association places it under the vegetation which we distinguish as Natural Pasture (Pa.). Other examples on this map are similarly indicated, but the chief development occurs in Part II. of this survey.

Aquatic and Marsh Vegeration.-From the high moorland to the lowland there is an interesting change in the hydrophytic vegetation. The chief associations have been dealt with as they were found with 
the types of drier vegetation, but it seems advisable to draw them together now. The course of any stream presents, in succession, the flat or gently sloping gathering grounds, the zone of rapid descent, and the zone of low gradient with slow currents. The extent of the three zones depends on the topography and geology of the country. In the present map, the marsh vegetation of the gathering grounds is somewhat varied, and is found in (1) the wet Eriophorum moor, (2) the wet parts of the heather moor, and (3) the Molinia or wet grass heath, all of which have already been referred to. The clough swamp is to be regarded as an accessory gathering-ground, where the waters of the moor are augmented by other springs exposed in the cutting back of the clough head. The clough swamp indicates a double change in the stream: the chief zone of rapid descent begins here, and the stream enters the woodland zone. Both changes have a distinct effect on the vegetation. The presence of alders, willows, and other trees favours the increase of shade-preferring plants, but the high altitude, with its severer climate, limits the number of species. The rapid drainage of this zone is not favourable to the formation of reaches of still water, hence the reed-swamp is not represented; but small marshes may form, and some moisture-loving marginal plants occur (Fig. 9). The intermediate zone of marsh vegetation (see p. 392) appears when the streams approach the Coal Measures, and form swampy areas favourable to the aquatic and marsh vegetation of the lowlands. The presence of numerous canals and reservoirs also brings the lowland vegetation up into this zone; this has been shown for the parish of Halifax by Mr. Crump (1901), and Mr. Moss (1900). The true lowland aquatic vegetation occurs in stagnant or slow-moving waters, either on the Coal Measures or on alluvial deposits of the rivers. The more inportant of these are indicated on the map, and include swampy marshes and subsidences due to coal-mining. The aquatic vegetation here considered is that of altitudes below 300 feet (90 metres). The area is entirely fresh-water, but plants of the maritime type begin to appear immediately to the east of the present map. Owing to extensive river pollution, the aquatic vegetation is inferior to that of the area north of this (see Part II.). The following may be found:-

I. Free-floating plants-

Utricularia vulgaris, L.

Stratiotes Aloides, I. Rare.

Ceratophyllum demersum, T. Rare.

Lemna minor, $\mathrm{L}$.

Hydrochuris Morsus-ranæ, $\mathrm{L}$.

L. trisulca, L.

II. Rooted plants with submerged or floating leaves-

Ranunculus aquatilis (agg.).

Hippuris vulgaris, $\mathrm{I}$.

Myriophyllum alternifolium, DC.

Hottonia palustris, L.

Polygonum amplibium, L.
Potamogeton natuns, $\mathbf{L}$.

P. crispus, $\mathrm{L}$.

I. pectinatus, $\mathrm{I}$.

Zannichellia palustris, I. 


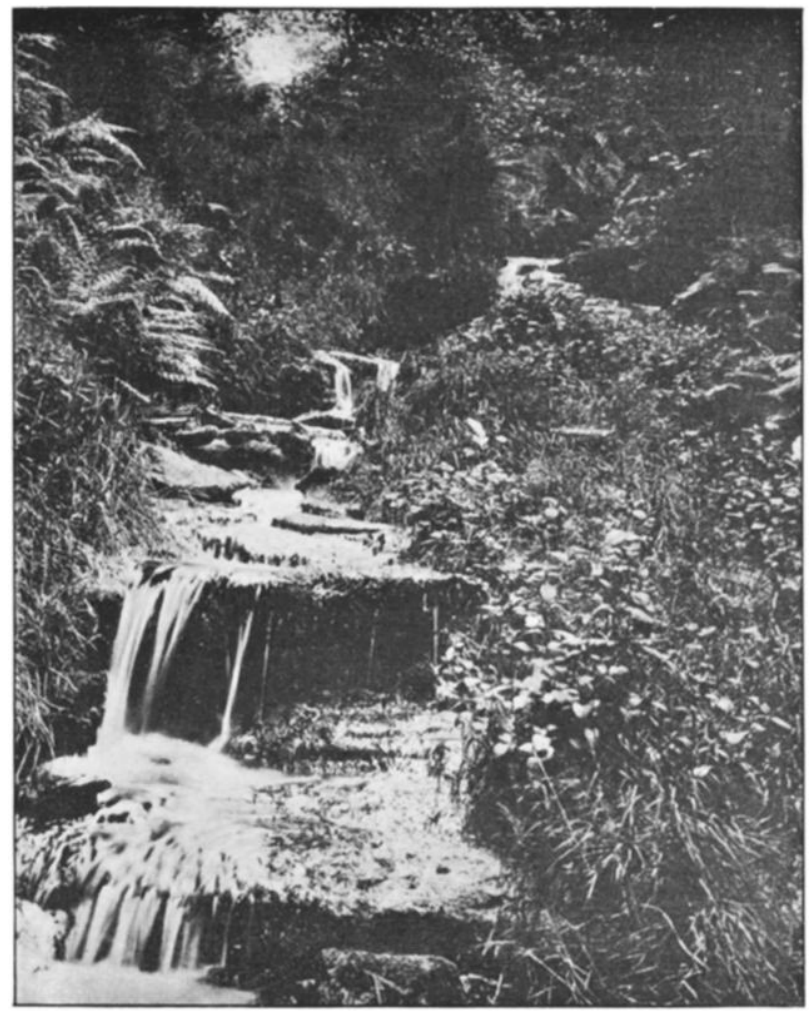

FIG. 9. Oak wood. Clough stream with marginal vegetation. 
III. Reed swamp; plants with elongated leaves-
Lythrum Salicaria, L.
Iris Pseudacorus, L.
Typha latifolia, L.
Sparganium ramosum, Huds.
S. simplex, Huds.
Acorus Calamus, L.
Alisma Plantago-aquatica, $\mathrm{L}$.

Sagittaria sagittifolia, L.

Butomus umbellatus, L.

Phragmites communis, Trin.

Glyceria aquatica, Sm.

Equisetum limosum, Sm.

E. palustre, L.

E. maximum, Lam.

IV. Marginal plants of the marsh (see al£o p. 388)-

Ranunculus sceleratus, I.

Caltha palustris, $\mathbf{L}$.

Nasturtium amphibium, R.Br.

Barbarea vulgaris, R.Br.

Epilobium hirsutum, I.

Sium erectum, Huds.

Enanthe Plellandrium, Lam.

Bidens tripartita, L.

Lysimachia vulgaris, L.

Scrophularia aquatica, I.

Lycopus europæu\&, I.

Stachys palustris, $\mathrm{L}$.

Carex acuta, L.

C. riparia, Curt.

The algæ have been recorded by Mr. W. West, of Bradford (1902).

(2) Cultivated Land.- The crops grown on the farmland indicate its capacity in regard to vegetation. The Board of Agriculture returns (1901) of the crops of the whole West Riding (of which the present map includes nearly one-third) are-

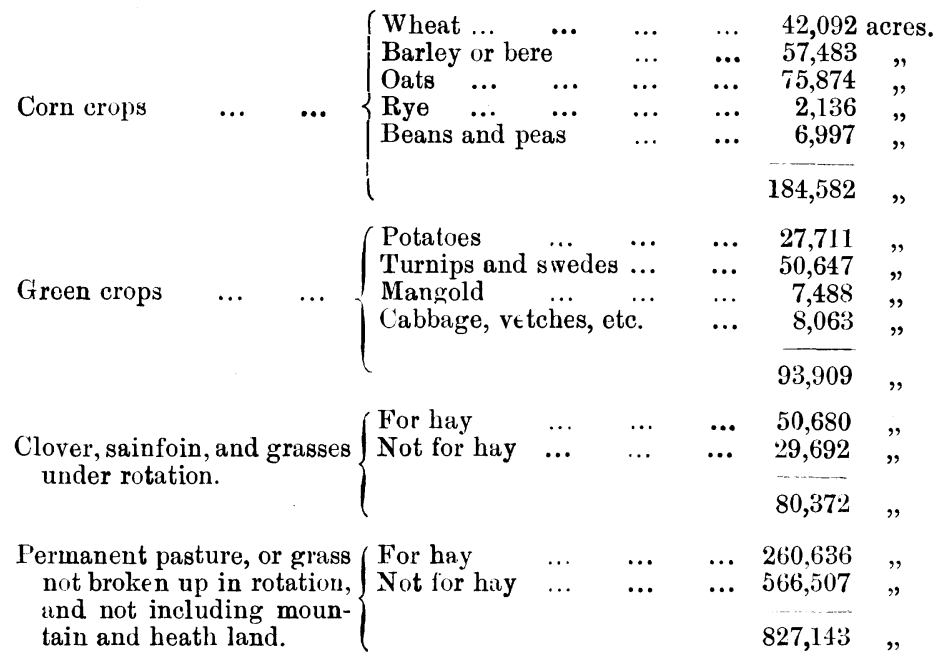

On the eastern lowlands and in the wide valleys of the Coal Measures, the farm rotations include all the crops given above. As the altitude increases towards the west, the cultivation of mangold, wheat, and the finer barleys gradually ceases, till on the upland farms the only crops of the ploughed land are oats, turnips, and the hardy bere (barley). At present the western part is almost entirely grass-land, and ploughed fields are only occasionally found. The farmland on the vegetation map is subdivided into a lower or wheat zone, and an upper or " no wheat" zone. Wheat is here taken as an indicator-plant, because it is already recognized as such in existing vegetation maps. Our wheat zone 
represents in Britain the warmer parts of Central Europe. The area of the possible cultivation of wheat in Britain presents an interesting problem in plant distribution, because we have a gradual reduction of the area from south to north, and a well-marked limit in altitude. The restricted distribution does not appear to depend on soils alone, and one must look more to climatic factors as determining its range. The recording of the upper limit on these maps furnishes material for examining what the conditions really are. The problem, however, is one for special consideration, with the assistance of experienced meteorologists. The most important climatic condition required for the successful ripening of wheat is a hot summer relatively dry, and this can only be obtained where the rainfall is low. The rainfall and the average summer heat of a district are therefore determining factors. Since wheat is generally sown in autumn, and the young plants pass through the winter, the climatic conditions of that period must also have an influence. Dr. Herbertson, who has kindly assisted us in this matter, summarizes the necessary conditions as a function of (1) sunshine, (2) temperature, (3) moisture, (4) rainfall, (5) ground watersupply, during the whole growth-period. The climatology of Yorkshire in its relation to the distribution of various plants has been suggestively, but in a general way, discussed both by Mr. Lees (1888) and Mr. Baker (1885). Dr. Buchan (1862) gives $56^{\circ}$ Fahr. (13 ${ }^{\circ}$ C.) as the average summer temperature required for the ripening of wheat in Scotland. In the Edinburgh district, R. Smith (1900) gives tables showing the mean July temperature and the rainfall at various stations. It appears from these that wheat ceases to be a regular crop of the farm at an altitude where the mean July temperature is below $56^{\circ} \mathrm{Fahr}$. and the rainfall exceeds 32 to 33 inches per annum. Summarizing the rainfall in the present map, Dr. H. R. Mill says, "It is under 30 inches (76 cms.) east of a line through Pudsey, Cleckheaton, and Cawthorne: a roughly parallel line at from 5 to 8 miles westwards indicates the beginning of rainfalls over 46 inches, except in the valley of the Aire, where it is between 30 and 40 inches." The following table gives data :-

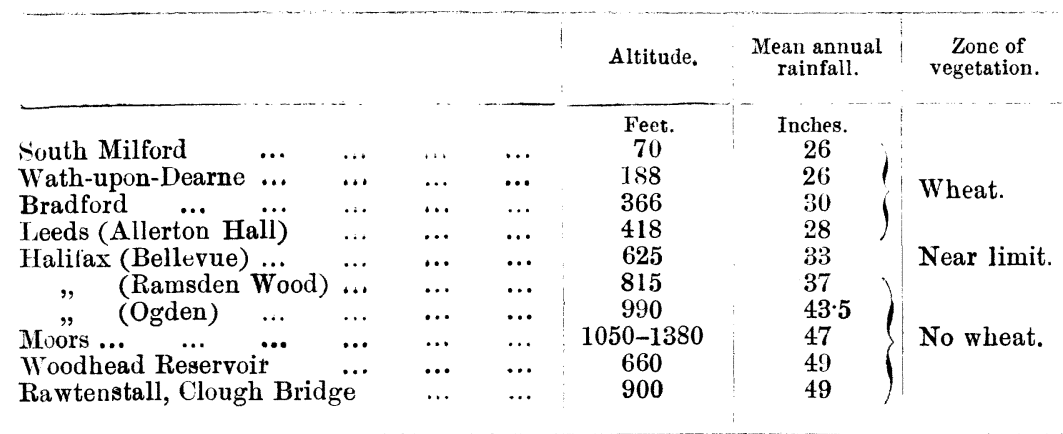


The mean July temperature at Bradford, at 366 feet (Y.N.U. Trans., 1900 ), is given as $59^{\circ} .5 \mathrm{Fahr}$. (adopted mean for twenty-eight years). Mr. Crump (1901) gives statistics from two stations at Halifax; one at 526 feet gives the average from June to August as about $59^{\circ} \mathrm{Fahr}$, another at 625 feet gives $56^{\circ} \mathrm{Fahr}$. for the same period. From the maps in the volume on meteorology of Bartholomew's Physical Atlas (1899), it is fairly safe to assume that in the present area up to 900 feet (273 metres) the mean temperature for July is over $56^{\circ} \mathrm{Fahr} .\left(13^{\circ} \mathrm{C}\right.$.). The evidence for Yorkshire therefore supports the Scottish results-that throughout the wheat zone indicated on the map the average July temperature is at least $56^{\circ} \mathrm{Fahr}$, and the rainfall is below 33 inches. In considering the woodland, we have already pointed out that the oak woods below about 500 feet (that is, within the wheat zone) have a type of vegetation richer in species than the upper oak belt. The patches of uncultivated land found within the wheat zone are too few to allow of any definite conclusions, yet they also present a more varied regetation than the upland moors. In the farmland the upper and lower zones are recognized, not only by the crops, but also by the weeds of cultivation and the regetation of the cultivated grass-land. The aquatic vegetation of the lowlands is also much richer in species than the "no wheat" zones.

The determination of a precise line to indicate the upper limit of the wheat area is rendered difficult at the present time by certain economic conditions. The declining price of wheat for many years has led to a marked shrinkage in the acreage devoted to it, and to an increase in grass-land. The returns of the Board of Agriculture (1891) for the whole West Riding show this :-

\begin{tabular}{|c|c|c|c|c|c|c|c|}
\hline 187 & & $\cdots$ & $\begin{array}{l}\text { Acres. } \\
103,910\end{array}$ & $\ldots$ & & 90 acres & per \\
\hline 88 & & $\cdots$ & 75,142 & $\ldots$ & $\ldots$ & 63 & land (not includ \\
\hline & & & 58,614 & $\ldots$ & $\ldots$ & 48, & ries, woods, or u \\
\hline & & $\ldots$ & 42,092 & & & - & moor or heath). \\
\hline
\end{tabular}

The reduction of wheat cultivation is evident orer the whole area, but is most marked (1) in the vicinity of towns and manufacturing districts, where the conditions for growth are less favourable, and where dairy farming or market gardening is more profitable; (2) on poor, especially light, lands, which are unfavourable to the winter growth of autumn-sown wheat; (3) towards the upper limits of the wheat zone. The last-mentioned area of shrinkage is the most important for this survey, because it affects the determination of the upper limit of wheat. During the progress of the survey, wheat has always been recorded on the field maps, either from observation or from reliable information. In some districts it has been ascertained that wheat was grown, but the crop was uncertain, ripening only in favourable seasons; in other words, its upper limit was ascertained. On the map the letter "W" No. IV.--AprIL, 1903.] 
above 500 feet (152 metres) indicates an actual observation on that spot, and the line defining the lower zone of cultivation from the upper is drawn from an average of these upper records. The average height of this line is from 600 to 700 feet, declining in the narrow western valleys to 400 feet. In the survey of the Edinburgh district, R. Smith fixed the wheat limit at 500 feet on northern exposures, rising to 700 feet on southern.

A transition zone between wheat and no-wheat was considered necessary to represent certain areas where wheat is now found occasionally over 700 feet, and was formerly grown to a larger extent. From the economic aspect of the present day, these transition areas cannot be considered as wheat-producing, but from the point of view of plant-geography it is necessary to indicate on the map that wheat may be grown there. The transition area occurs at an altitude of 800 to 1000 feet, near the junction of the Millstone Grit and lower Coal Measures. The Coal Measure valleys are wide, with gentle slopes, rising to comparatively low watersheds; these conditions are favourable for the cultivation of wheat, as our records show, up to the watershed. West of the Holme valley the transition area occurs on gentle slopes on the Millstone Grit, e.g. Honley Moor. It is noteworthy that this transition zone occurs on or about the rainfall line of 30 inches. In general aspect the vegetation of this zone is poor in species, and has more affinity with that of the no-wheat and moor-edge areas than with the true wheat zone. We therefore considered it advisable to represent it as shown on the map. In a more detailed survey, using maps on a larger scale and taking the underlying soils into consideration, the vegetation of the cultivated farm lands would be better represented by further subdivision. Such a survey would require careful investigation, and could be undertaken only by those having access to returns of crops, such as are furnished alnually to the Board of Agriculture.

The weeds of arable land are chiefly annuals, many of which also occur in gardens or other freshly turned land. The greatest variety of weeds is found at low altitudes and in the richer land of the wheat zone; with increasing altitude many of the species cease to be prominent weeds and become casuals. The practice of using seed grain imported from a new district aids in spreading weeds, hence lowland species may be recorded occasionally at higher altitudes than usual, but they soon die out unless suited to the lccality. A list of eighty-four weeds of arable land in Yorkshire, when arranged according to the altitudes given by Lees (1888), show about forty-four occurring above the wheat line; but these altitudes are the range of the species, not its range as a weed, which is generally lower. In a list of "One Hundred Yorkshire Weeds," compiled by us for the Agricultural Department of the Yorkshire College, sixty-three are common weeds of arable land; and 
of these not more than forty-two occur above the wheat line. The following is a short list of characteristic species :-

Chiefly in Wheat Zone.

Papaver Rhras, L.

Raphanus Raphanistrum, L.

Viola arvensis, Murr.

Lychnis Githago, Scop.

AEthusa Cynapium, L.

Scandix Pecten-Veneris, L.

Matricaria Chamomilla, L.

Chrysanthemum segetum, $\mathrm{L}$

Sonchus arvensis, $\mathbf{L}$.

Chenopodium album, I.

Polygonum Convolvulus, L.

Euphorbia exigua, L.
IN Both ZoNes.

Bursa Bursa-pastoris, Web.

Brassica Sinapistrum, Boiss.

Viola tricolor, L.

Stellaria media, Cyr.

Spergula arvensis, $\mathrm{L}$.

Matricaria inodora, L.

Tussilago F'arfara, L.

Senecio vulgaris, L.

Sonchus asper, Hoffm.

Atriplex patula, I.

Polygonum aviculare, $\mathrm{L}$.

Euphorbia Peplus, L.

Grass-land.-A large proportion of the farm-land is now left permanently as grass, but almost every field shows the ridges and furrows left on land which has been ploughed. In reclaiming the land from moor or heath, it is usual to enclose and plough it, and after taking one or more crops from it, to sow down with grasses. Many of the fields in the upper zone have probably only been once ploughed, but generally the land has been broken up oftener. The grass-land of the no-wheat zone of the western uplands is, as a rule, poorly cultivated. The mixed herbage yields one crop of hay each summer, and is then grazed till winter. In spring, the manure from stables and yards is distributed over the fields, and beyond this, little manuring takes place. On some farms, lime is applied at intervals of a few years, and on this soil, consisting chiefly of sands and shales, the beneficial result on the herbage is very marked.

In the eastern lowland part of the map, over the Coal Measures, more land is regularly ploughed, but a considerable acreage is permanently grass. Some of the grass-fields are used only for grazing : others are reserved for meadow hay. The meadows yield one or two crops of hay annually, and are well manured to encourage the larger grasses. Sward-forming grasses are preferred on the pastures. In regard to the numerous associates of the grasses which together make up the sward of a pasture or meadow, we have compared their range of distribution, and find that a considerable proportion cease at about 600 feet, others at 900 feet, while the rest ascend to altitudes above 1250 feet.

The pastures and meadows overlying the Permian limestone have a characteristic vegetation. In early summer especially, their bright green colour contrasts strongly with the dull green of pasture on adjoining formations. The constituents of the Permian vegetation are reserved for Part II. of this survey. 


\section{LIST OF REFERENCES.}

Agriculture, BoARD of.- 'Agricultural Returns of Great Britain.'

Baker, John Gilbert.-(1885.) "North Yorkshire: Studies of its Botany, Geology, Climate, and Physical Geography." 2nd edit. Trans. of Yorks.

Nat. Union, 1885-1891. The work is complete up to Grasses, but further parts are to be published. Apply, Hon. Sec. Y.N.U., Museum, Hull.

Bartholomew's Physical Atras. - Edinburgh and London (Constable). Vol. iii. Atlas of Meteorology, 1899.

Buchan, Alex.-(1862.) "The Meteorological Conditions which determine the Profitable or Unprofitable Culture of Farm Crops in Scotland." Quarterly Rep. Meteorol. Soc. of Scotland, 1862, pp. 2-12. Also other papers.

Crump, W. B.-(1901.) ' The Flora of the Parish of Halifax.' This book has been issued in parts with the Halifax Naturalist, and is not yet complete. The Introduction (from June, 1900, to August, 1901) is the part we generally refer to.

Davis, J. W., and Lees, F. Arnold.-(1880.) ' West Yorkshire : Geology, Physical Geography, Climatology, and Botany.' London, 1880.

Engler und Drude.-(1897.) 'Die Vegetation der Erde.' Monographs i. to vi. Leipzig (Engelmann), 1897 to 1902.

Flahault, Ch.-(1897.) "Essai d'une Carte Botanique et Forestière de la France." Ann. de Geog., No. 28, 1897, pp. 289.312 (with map).

Fry, Sir E.-(1892.) 'British Mosses.' Knowledge Series. London (Witherby), 1892.

Graebner, P.-(1901.) 'Die Heide Norddeutcchlands.' Part v. Engler und Drude. 'Vegetation der Erde.' Leipzig (Engelmann), 1901.

Halifax Naturalist.-Editor, W. B. Crump, Halifax, Yorks.

Lees, Davis and.-(1880.) See Davis.

Lees, F. Annold.-(1888.) 'The Flora of West Yorkshire.' London, 1888. See also DAvis.

Moss, C. E.-(1900.) 'Changes in the Halifax Flora.' Naturalist, 1900.

Naturalist. Journal of Yorks. Naturalist Union.

Rothery, Lister.-(1900.) “ Flora of Skipton and District." Skipton, 1900.

Smith, Robert.-(1898.) "Plant Associations of the Tay Basin." Part i. Proc. Perthshire Soc. of Nat. Sci., vol. ii. 1898.

- (1899.) "On the Study of Plant Association." Natural Science, xiv., 1899, pp. 109-120 (with a full bibliography of works relating to this subject).

- (1900.) 'Botanical Survey of Scotland: I. Edinburgh District; II. Northern Perthshire.' John Bartholomew \& Co., Edinburgb, 1900. Also Scot. Geog. Mag., July and Angust, 1900.

Sмith William G.-(1902A.) "A Botanical Survey of Scotland." Brit. Assoc., Glasgow, 1901, Sect. E. Also Scot. Geog. Mag., March, 1902.

- (1902в.) "The Origin and Development of Heather Moorland." A review of Graebner (1901), with special reference to recent work in Britain. Scot. Geog. Mag., November, 1902.

Thurmann, Jules.-(1849.) 'Essai de Phytostatique applique à la chaine du Jura.' Berne, 1849 ; London : Williams \& Norgate.

United States Department of Agriculture.-(1898.) Merriam, C. H. 'Life Zones and Crop Zones of the United States.' Bulletin No. 10, Division of Biological Survey, Washington, 1898. Forest maps have also been prepared.

Warming, E.- 'Lehrbuch d. okologischen Pflanzengeographie.' German edition by Knoblauch, Berlin, 1896. 
WA'son, H. C.-(1836.) "Observations on the Construction of Maps for illustrating the Distribution of Plants." Mag. Nat. Hist., ix., 1836, pp. 17-21.

- (1843). 'Geographical Distribution of British Plants.' London, 1843. 'Cybele Britannica' and 'Compendium.' London, 1847-1870.

West, W. and G. S.-(1902.) “The Alga-Flora of Yorkshire." Trans. Yorks. Nat. Union, Botanical Series, vol. v. From Hon. Sec. Y.N.U., Museum, Hull. Yorkshire Naturalists' Union, Transactions of.

\section{FROM QUITO TO THE AMAZON VIÂ THE RIVER NAPO.}

By A. HAMILTON RICE, B.A., F.R.G.S.

ON August 12, 1901, after the usual delay incidental to the departure upon every journey in South America, either for small distances or great, five miserable specimens of animals, claimed to be horses and mules, two arrieros, my negro servant and I turned our backs upon Quito, bound for the Indian village of Papallacta, two days distant. Mr. Söderström, the English consul, who had been my friend and benefactor in every possible way during my stay in Quito, accompanied us out of the city some 4 miles, bidding me God-speed, near the crumbling church dedicated to the Virgin of Guadeloupe, which marks the village of Guapulo. There is a fair road, first through the hills and then upon the open, with signs on all sides of Cotopaxi's violence, to the feverinfested and lifeless village of Tumbaco, where it is said no stranger can pass the night without contracting severe fever; and its hygienic conditions may be judged iby the fact that its enterprising inhabitants let their dead remain unburied for days, never removing them from the huts, the natural decomposition process being aided by flocks of the carrion crow, or gallinazo, so called. Here some change of beasts was made, and the number increased from five to six, as the road was reported to be in bad condition-bad in Ecuador would be execrable, if not impassable, elsewhere.

The trail from 'Tumbaco is a sandy one, through a dreary country of a monotonously undulating character, with a stream to be crossed which reaches the flanks of the animals. About sunset, shortly after getting into the hills, the low rambling buildings of the hacienda Itulcachi appeared in view, and in a short time we were past the heavy gateway, and in the spacious courtyard the Indian retainers in a leisurely way helped the arrieros to unpack the loads, while a tall, big-limbed young fellow went to summon the master in charge. He soon appeared, a typical Ecuadorian, in a large, high-pointed, broad-rimmed hat, a serviceable poncho, wide trousers, and big spurs; he accorded me a hearty welcome, extending both hands to grasp mine, and the look of cordiality and good feeling which overspread his lean, leathery, and bronzed countenance more than made up for the words he wished to 

